\title{
Reducing the social exclusion of girls
}

Kelly Hallman

Population Council

Eva Roca

Population Council

Follow this and additional works at: https://knowledgecommons.popcouncil.org/departments_sbsr-pgy

Part of the Demography, Population, and Ecology Commons, Family, Life Course, and Society

Commons, Gender and Sexuality Commons, International Public Health Commons, and the Medicine and Health Commons

How does access to this work benefit you? Let us know!

\section{Recommended Citation}

Hallman, Kelly and Eva Roca. 2007. "Reducing the social exclusion of girls," Promoting Healthy, Safe, and Productive Transitions to Adulthood Brief no. 27. New York: Population Council. 


\section{Reducing the social exclusion of girls}

\section{Prepared by Kelly Hallman and Eva Roca}

A cross the globe, girls are systematically excluded from participation in social, economic, and political life. The absence of girls in these arenas has implications not only for the young women themselves but also for society as a whole, exacerbating poverty and perpetuating disparities in health, education, and economic achievement. Internationally, this marginalization makes it difficult or impossible for some countries to achieve society-wide goals, such as the Millennium Development Goals identified by the United Nations as benchmarks to reduce poverty.

Female social exclusion begins early in life and is especially notable at life transitions such as puberty and marriage. Exclusion is also evident in many of the obstacles girls encounter during the transition to adulthood. Adolescent girls encounter barriers to entering and staying in school, finding work, making friends, learning life skills, accessing health services, and participating in civic life. In some parts of Asia, sex-selective abortion and female infanticide reduce girls' chances of even starting life (Drèze and Sen 1989).

For a number of years, the Population Council has been studying the causes and effects of girls' social exclusion in developing countries, with projects in Asia, Africa, and Latin America.

\section{Which girls are most excluded?}

Girls' exclusion is most pronounced in countries that are extremely poor and those where women have been historically marginalized (such as in the Middle East). In many developing countries, the interaction of gender, culture, and poverty underlies female social exclusion. Recent estimates indicate that three-fourths of the 60 million girls aged 6-11 who are not in school belong to ethnic, religious, linguistic, racial, or other minorities (Lewis and Lockheed 2006). Girls who belong to these minorities suffer disproportionately relative to their male peers and to girls in the mainstream population. For example, among seven-year-olds in Guatemala in 2000, only 54 percent

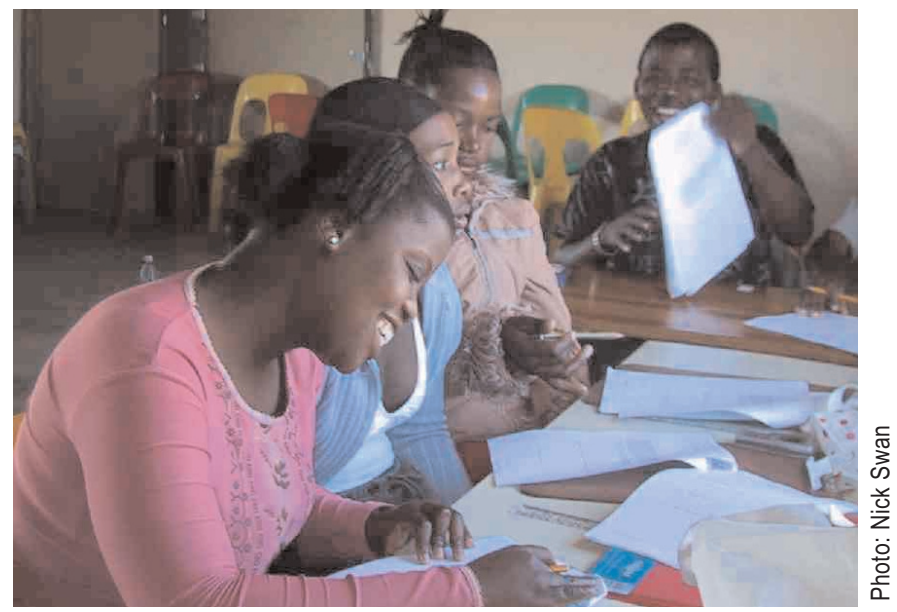

Because mobility is restricted for many girls, the primary requirement for social inclusion is a safe, supportive space where they can interact with peers and mentors.

of indigenous girls were enrolled in school, compared with 71 percent of indigenous boys and 75 percent of non-indigenous children. Among extremely poor indigenous girls the proportion enrolled was 43 percent (Hallman et al. 2007b).

In some instances, obstacles raised by gender, poverty, and ethnicity are compounded by geographic exclusion-being from "the wrong side of town" or residing in a remote community. Girls tend to have limited mobility relative to their male counterparts, so services and opportunities that are not in a girl's immediate neighborhood can be far out of reach. Girls may also lack the financial means to travel safely to access employment or educational opportunities.

\section{Girls' social exclusion is a barrier to development}

The social exclusion of girls perpetuates poverty at the individual and household levels by denying them access to education, services, resources, decisionmaking, and markets. Expectations and actual experiences of exclusion and discrimination can cause feelings of powerlessness among those left out, which may in turn result in low self-esteem and diminished 
aspirations for the future. Research has shown that these feelings can lead to lower achievement among members of excluded groups. For instance, a study in India found that young people from low-caste and high-caste backgrounds performed equally well on tests when information about their caste was not disclosed. When castes were publicly announced, however, the low-caste children performed worse than their high-caste peers (DFID 2005). If parents expect that their daughters will be discriminated against in the labor market, they may choose not to invest in their education. As one young girl participating in a Council project in Guatemala (Colom et al. 2004; Dries-Daffner et al. 2007) noted,

At times it's just because we're women that they won't pay for our education, and they say that only boys should [study], because they're more intelligent. Some people tell my father, "Don't support her studies because she won't do what you want, you'll only waste your money and she'll get married and won't finish school, you better not send her to school."

In areas severely affected by HIV and AIDS, expectations of a shortened lifespan may serve to discount the value of the future and reduce human capital investments. Saving for the future or forgoing fulfilling activities today in order to be healthy and well-educated tomorrow may not seem sensible to girls threatened by HIVIAIDS. Conversely, results from South Africa indicate that girls with more future-oriented attitudes (e.g., those who have financial goals and are saving) are more knowledgeable about HIV and more likely to practice HIV-prevention behaviors (Hallman et al. 2007a).

The social exclusion of girls has consequences at the country level. Even when national economies grow, excluded groups are left behind. Social isolation and relative economic deprivation are associated with poorer mental health, especially among females, and can further reduce the ability of excluded individuals to be productive members of society (Patel and Kleinman 2003). As the gap between the poor and non-poor increases, poverty becomes deeper and more intractable.

\section{Underlying causes of girls' exclusion}

Whether intentional (due to tradition or discrimination) or unintentional (due to a desire to protect girls from harm or threats to their chastity), the outcome is the same: girls' lives are in every way more limited than those of boys.

Starting at an early age, girls residing in the same communities and households as boys are more excluded from investments and opportunities. In many settings, puberty is the time when gender role expectations become differentiated and intensified. Boys experience more freedom of decisionmaking and mobility, while the movement of girls outside the domestic sphere becomes increasingly circumscribed (Mensch et al. 2003), often because of parents' fear of male attention, the temptation of unsanctioned activities, and the potential damage to their daughters' reputations (Brady 2003; Colom et al. 2004). That boys are given the bulk of household attention, resources, and freedom is linked to the perception that boys contribute more to the household economy and that they can be counted on for old-age security of parents. In contrast, girls are perceived to contribute less in terms of their labor and income-generating capacity, and, in some contexts, are even seen as a drain on household finances because of the costs associated with their marriage. The extra investment in boys is evident in their achievements relative to girls in education, literacy, and participation in the labor force.

Population Council research provides evidence from a number of settings that adolescent girls lack protective social networks and support. In Allahabad, India, 93 percent of boys but only 22 percent of girls reported being able to travel unaccompanied to visit a relative (Sebastian et al. 2004). In the urban slums of Nairobi, two-thirds of boys, compared with only one-third of girls, reported having a safe place to meet samesex friends (Erulkar and Chong 2005). Among adolescents in Addis Ababa, Ethiopia, boys reported an average of 4.7 friends compared to girls with 2.7 friends (Erulkar et al. 2004a). In KwaZulu-Natal, South Africa, 76 percent of boys versus 48 percent of girls reported having many friends. Poorer girls reported having the fewest friends, and even girls in the richest wealth quintile had fewer friends than boys in the poorest quintile (Hallman and Diers 2004). In Ethiopia and South Africa, girls were significantly more likely to feel insecure in their neighborhood and to have experienced harassment; they were also less likely to report they had sources of support during times of crisis (a place to stay or someone to borrow money from). In rural areas of both Guatemala and Ethiopia, boys were much more likely than girls to have engaged in social events (Colom et al. 2004; Erulkar et al. 2004b). In rural Upper Egypt, the only non-familial social outlet for girls is attending school (Brady et al. 2007).

For many girls, marriage is the only socially acceptable avenue for exiting a poor and overly protective natal home, and many girls eagerly anticipate marriage with the view that it will expand their social horizons (Colom et al. 2004; Brady et al. 2007). This expectation frequently does not materialize, however. Council research shows that married girls have 
more limited peer networks (Amin, Mahmud, and Huq 2002), less social mobility and freedom (Erulkar et al. 2004b; Santhya and Jejeebhoy 2003), more limited access to media and other sources of information (Erulkar et al. 2004b; Amin, Mahmud, and Huq 2002), and lower educational attainment (Mensch 2005) than their unmarried age mates. Compared with women who marry later, married adolescents have husbands much older than themselves (Clark, Bruce, and Dude 2006; Mensch, Bruce, and Greene 1998). They also have less freedom of movement (Amin, Mahmud, and Huq 2002), less autonomy and decisionmaking in household and reproductive decisions (Santhya and Jejeebhoy 2003), and, in some settings, increased risk for gender-based violence (Kishor and Johnson 2004), sexually transmitted infections, and HIV infection (Clark, Bruce, and Dude 2006).

\section{Promising strategies for including adolescent girls}

Although there is still much work to be done, several approaches are proving beneficial for girls. Because mobility is restricted for many girls, especially at the approach of puberty, the primary requirement for their social inclusion is a safe, supportive space where they can interact with peers and mentors, strengthen their social networks, and enjoy freedom of expression and movement. Safe spaces for girls can serve as locations for any number of beneficial services, including financial and business education, health interventions, assertiveness training, and skills building for sexual negotiation. Safe spaces also act as a foundation for building girls' capacity to organize and mobilize themselves.

To fully participate in civic life, girls need access to documentation, such as ID cards and other government documents. They also require access to health and other youthoriented services. The results of several Council studies reveal that the most socially isolated adolescents are the least likely to have contacts with youth centers, adolescentfriendly clinics, and peer education programs (Lardoux and Jones 2006). Ironically, the very adolescents most in need of services-girls who are young, poor, rural, married, not attending school, and/or living without one or both parentsare the most underrepresented (Bruce et al. 2006; Lardoux and Jones 2006). Efforts must be made to increase available services and ensure girls' access to those services.

\section{Program recommendations}

Poverty reduction and other programs must be designed to effectively reach these excluded girls and provide them with information and services. To succeed, programs must learn from and adapt to the local context. Additionally, programs can help empower girls by changing community attitudes. If parents and other gatekeepers recognize the value of including girls, they are more likely to become a visible part of their community. Council work in Egypt (Brady et al. 2007) demonstrated that it is possible to change community attitudes about girls.

\section{Research gaps}

Additional research is needed across the globe to learn more about which girls are excluded, to examine the effects of isolation on their lives, and to develop context-specific approaches to meet girls' needs. By disaggregating existing data (such as the Demographic and Health Surveys and other countrywide data), researchers may gain a better understanding of the trends behind the averages. The relationship between girls' social exclusion and their rights must be analyzed further. Researchers should also explore the negative effects of social exclusion on poverty reduction and achievement of the Millennium Development Goals, as well as other human development measures. In the end, girls' rights are human rights. Socially isolated girls are a group that we cannot afford to leave behind.

\section{References and related publications}

Amin, Sajeda, Simeem Mahmud, and Lopita Huq. 2002. "Baseline survey report on rural adolescents in Bangladesh." Dhaka: Ministry of Women's Affairs, Government of Bangladesh.

Brady, Martha. 2003. "Safe spaces for adolescent girls," in Adolescent and Youth Sexual and Reproductive Health: Charting Directions for a Second Generation of Programming (background documents). New York: UNFPA, pp. 155-176.

Brady, Martha, Ragui Assaad, Barbara Ibrahim, Abeer Salem, Rania Salem, and Nadia Zibani. 2007. Providing New Opportunities to Adolescent Girls in Socially Conservative Settings: The Ishraq Program in Rural Upper Egypt. New York: Population Council.

Bruce, Judith, Nicole Haberland, Erica Chong, Monica Grant, and Amy Joyce. 2006. "The girls left behind: The failed reach of current schooling, child health, youth-serving, and livelihoods programs for girls living in the path of HIV," Policy paper. New York: Population Council.

Clark, Shelley, Judith Bruce, and Annie Dude. 2006. "Protecting young women from HIVIAIDS: The case against child and adolescent marriage," International Family Planning Perspectives 32(2): 79-88.

Colom, Alejandra, Marta Julia Ruiz, Jennifer Catino, Kelly Hallman, Sara Peracca, and Kristen M. Shellenberg. 2004. "Voices of vulnerable and underserved adolescents in Guatemala." Guatemala City: Population Council.

DFID. 2005. "Reducing poverty by tackling social exclusion: A DFID policy paper." London: DFID. 
Drèze, Jean and Amartya Sen. 1989. Hunger and Public Action. Oxford: Clarendon Press.

Dries-Daffner, Ingrid, Kelly Hallman, Jennifer Catino, and Karla Berdichevsky. 2007. "Guatemala," in International Encyclopedia of Adolescence, 2 vols., ed. Jeffrey J. Arnett. New York and London: Routledge.

Erulkar, Annabel and Erica Chong. 2005. "Evaluation of a savings and micro-credit program for vulnerable young women in Nairobi." Nairobi: Population Council.

Erulkar, Annabel S., Tekle-Ab Mekbib, Negussie Simie, and Tsehai Gulema. 2004a. "Adolescent life in low income and slum areas of Addis Ababa, Ethiopia." New York: Population Council.

Erulkar, Annabel S., Tekle-Ab Mekbib, Negussie Simie, and Tsehai Gulema. 2004b. "The experience of adolescence in rural Amhara Region, Ethiopia". New York: Population Council.

Erulkar, Annabel S., Tekle-Ab Mekbib, Negussie Simie, and Tsehai Gulema. 2006. "Migration and vulnerability among adolescents in slum areas of Addis Ababa, Ethiopia." Journal of Youth Studies 9(3): 361-374.

Hall, Gillette and Harry Anthony Patrinos. 2004. Indigenous Peoples, Poverty and Human Development in Latin America. New York: Palgrave Macmillan.

Hallman, Kelly and Judith Diers. 2004. "Social isolation and economic vulnerability: Adolescent HIV and pregnancy risk factors in South Africa," presentation at the Annual Meeting of the Population Association of America, April, Boston, MA.

Hallman, Kelly, Kasthuri Govender, Emmanual Mbatha, Jill Walsh, Rob Pattman, and Deevia Bhana. 2007a. "Social capital, socioeconomic aspirations, and HIV risk behaviors among poor South African youth," poster presentation at the Third South African AIDS Conference, June, Durban, South Africa.

Hallman, Kelly and Sara Peracca, with Jennifer Catino and Marta Julia Ruiz. 2007b (forthcoming). "A four-fold disadvantage: The effects of ethnicity, gender, poverty, and geography on education in Guatemala," in Maureen Lewis and Marlaine Lockheed (eds.), Exclusion, Gender and Education: Case Studies from the Developing World. Washington, DC: Center for Global Development.

Kishor, Sunita and Kiersten Johnson. 2004. Profiling Domestic Violence: A Multi-Country Study. Calverton, MD: ORC Macro.

Lardoux, Solene and Heidi Jones. 2006. "Capacity building for adolescent program and policy development in West Africa: Interim narrative report." New York: Population Council.

Lewis, Maureen A. and Marlaine E. Lockheed. 2006. Inexcusable Absence: Why 60 Million Girls Still Aren't in School and What to Do About It. Washington, DC: Center for Global Development.
Lloyd, Cynthia B., Cem Mete, and Monica Grant. 2007 (forthcoming). "Rural girls in Pakistan: Constraints of policy and culture," in Maureen Lewis and Marlaine Lockheed (eds.), Exclusion, Gender and Schooling: Case Studies from the Developing World. Washington, DC: Center for Global Development.

Mensch, Barbara S. 2005. "The transition to marriage," in Cynthia B. Lloyd (ed.), Growing Up Global: The Changing Transitions to Adulthood in Developing Countries. Washington, DC: National Academies Press, pp. 416-505.

Mensch, Barbara S., Judith Bruce, and Margaret E. Greene. 1998. The Uncharted Passage: Girls' Adolescence in the Developing World. New York: Population Council.

Mensch, Barbara S., Barbara L. Ibrahim, Susan M. Lee, and Omaima El-Gibaly. 2003. "Gender-role attitudes among Egyptian adolescents," Studies in Family Planning 34(1): 8-18.

Patel, Vikram and Arthur Kleinman. 2003. "Poverty and common mental disorders in developing countries." Bulletin of the World Health Organization 81(8): 609-615.

Population Council. Various years. "Facts about adolescents from the Demographic and Health Survey: Statistical tables for program planning" (various countries, for full list see: <http://www.popcouncil.org/gfd/gfdcountries.html>. New York: Population Council.

Santhya, K.G. and Shireen J. Jejeebhoy. 2003. "Sexual and reproductive health needs of married adolescent girls," Economic and Political Weekly 38(41): 4370-4377.

Sebastian, Mary P., Monica Grant, and Barbara Mensch. 2004. "Integrating adolescent livelihood activities within a reproductive health programme for urban slum dwellers in India." New Delhi: Population Council.

Shisana, O., T. Rehle, L.C. Simbayi, W. Parker, K. Zuma, A. Bhana, C. Connolloy, S. Jooste, and V. Pillay. 2005. South African National HIV Prevalence, HIV Incidence, Behavior and Communication Survey. Capetown: HSRC Press.

UNDP. 1995. Human Development Report 1995: Gender and Development. New York: Oxford University Press.

\section{Donors}

Department for International Development (DFID), The Dickler Family Foundation, EMPower-The Emerging Markets Foundation, Focus on Young Adults, The Ford Foundation, Bill \& Melinda Gates Foundation, The William H. Kaufman Charitable Foundation, MEASURE Evaluation, The Andrew W. Mellon Foundation, The Rockefeller Foundation, The Summit Foundation, Turner Foundation, United Nations Children's Fund (UNICEF), United States Agency for International Development (USAID)

\section{For more information or for copies of other briefs, contact publications@popcouncil.org For additional resources see www.popcouncil.org/pgy}

Population Council

One Dag Hammarskjold Plaza

New York, New York 10017 USA

(c) 2007 by The Population Council, Inc. 